\title{
Família e Orientação Sexual: Dificuldades na Aceitação da Homossexualidade Masculina
}

\author{
Mônica Magrini de Lima Silva ${ }^{1}$ \\ Juliana Fernandes Furlan Frutuozo \\ Faculdade de Medicina de São José do Rio Preto, São José do Rio Preto, SP, Brasil \\ Marianne Ramos Feijó \\ Departamento de Psicologia da Universidade Estadual Paulista Júlio de Mesquita Filho, \\ Bauru SP, Brasil \\ Nelson Iguimar Valerio \\ Departamento de Psiquiatria e Psicologia Médica da Faculdade de Medicina \\ de São José do Rio Preto, São José do Rio Preto, SP, Brasil \\ Ulisses Herrera Chaves \\ Universidade Paulista - UNIP, Bauru, SP, Brasil
}

\begin{abstract}
Resumo
O presente trabalho teve como objetivo compreender a vivência de homens com orientação homossexual e a construção dos significados da homossexualidade em suas respectivas famílias de origem, por meio das narrativas dos participantes. Participaram cinco pessoas do sexo masculino com orientação homossexual, residentes e domiciliados no interior do Estado de São Paulo, Brasil, que responderam a uma entrevista semi-estruturada e a perguntas para a construção de Genogramas. As narrativas foram compreendidas de forma qualitativa a partir da teoria sistêmica e novo paradigmática, também chamada de complexa, que implica considerar aspectos relacionais, processuais e contextuais na compreensão de fenômenos humanos. Os entrevistados relataram situações difíceis relacionadas a vivência da homossexualidade, inclusive no momento da decisão de contar para as famílias de origem. O estudo, compatível com dados da literatura, mostrou que os preconceitos socialmente mantidos em relação às diversas formas dos indivíduos vivenciarem sua sexualidade colaboram para as dificuldades na aceitação da homossexualidade masculina, ainda nos dias atuais.
\end{abstract}

Palavras-chaves: Homossexualidade, família, orientação sexual.

\section{Family and Sexual Orientation: Difficulties in Acceptance of Male Homosexuality}

\begin{abstract}
This article objectived to understand the living of men with homosexual orientation and the construction of meanings about homosexuality in their own families, through participant narratives. The participants this research were five male persons with homosexual orientation, resident and domiciled at São

Endereço para correspondência: Rua Odair Pedro, 145 - B, Zéquinha Amendola, Barretos, SP, Brasil 14781207. E-mail: silvamagrini@ig.com.bre j.furlan@hotmail.com

O presente artigo partiu de um Trabalho de Conclusão de Curso (TCC) do Curso de Pós-Graduação Latu Sensu - Especialização em Intervenção Familiar: Psicoterapia e Orientação Sistêmica, Faculdade de Medicina de São José do Rio Preto (FAMERP, 2012), sob orientação dos Professores Marianne Ramos Feijó, Nelson Iguimar Valério e Ulisses Herrera Chaves.
\end{abstract}


Paulo State's country, Brazil, who answered to a semi-structured interview and some questions for the Genogram's construction. The narratives were understood qualitatively through Systems Theory, also known as Complex Theory, and it implies considering relational, processual and contextual aspects for understanding human phenomena. The interviewed people reported tough situations related to a homosexuality experience, even at the moment which they reveal that situation for own families. This study, compatible with bibliographic data, showed that prejudices socially held, regarding several ways of individuals experience their own homosexuality, help to maintain the difficulties in the acceptance of male homosexuality, nowadays.

Keywords: Homosexuality, family, sexual orientation.

\section{Familia y Orientación Sexual: Las Dificultades en la Aceptación de la Homosexualidad Masculina}

\section{Resumen}

Este estudio tuvo como objetivo comprender la vivencia de los hombres de orientación homosexual y la construcción de los significados de la homosexualidad en sus respectivas familias de origen, por medio de narrativas de los participantes. Han participado cinco personas del sexo masculino, de orientación homosexual, residentes y domiciliadas en el Estado de São Paulo, Brasil, que respondieron a una entrevista semi-estructurada y a preguntas para la construcción de genogramas. Las narrativas fueron comprendidas de manera cualitativa a partir de la teoría sistémica y nueva paradigmática, también llamada compleja, que implica considerar aspectos relacionales, procesuales y contextuales en la comprensión de fenómenos humanos. Los entrevistados relataron situaciones difíciles relacionadas à la vivencia de la homosexualidad, incluso en el momento de la decisión de decir a las familias de origen. El estudio, compatible con datos de la literatura, mostró que los prejuicios mantenidos socialmente en relación a las distintas maneras a través de las cuales los individuos viven su sexualidad colaboran para las dificultades de la aceptación de la homosexualidad masculina, incluso en los días actuales.

Palabras clave: Homosexualidad, familia, orientación sexual.

As relações humanas e seus aspectos afetivo-sexuais devem ser compreendidos de forma que se leve em conta a cultura, o tempo, o lugar e os demais aspectos relacionais, contextuais e processuais que as envolvem (Vasconcelos, 2008). Muitas têm sido as mudanças observadas nas relações de intimidade e na expressão da sexualidade nos contextos públicos nas últimas décadas.

A sexualidade de cada pessoa é construída por meio dos aspectos biopsicossociais (Romualdo, 2007), que se interconectam e se influenciam de forma recursiva (Vasconcelos, 2008). A esse respeito, Sant Anna e Daspett (2007) pressupõem a existência de quatro pilares: o sexo biológico (macho/fêmea), a identidade sexual (masculino/feminino), a orientação sexual (homossexual/heterossexual/bissexual) e o aspecto psicológico (comportamentos, atitudes e senti- mentos). Porém, tais aspectos devem ser compreendidos de forma individual e contextualizados, ou seja, imersos em relações, ideologias e significados socialmente construídos (Grandesso, 2000).

A orientação sexual, segundo Sant Anna e Daspett (2007, p. 165), diz respeito a como cada pessoa reconhece seu desejo em diferentes fases da vida, podendo ser identificada como "assexual (nenhuma atração sexual), bissexual (atração por ambos os sexos), heterossexual (atração pelo sexo oposto) e homossexual (atração por pessoa do mesmo sexo)".

As relações homoafetivas têm sido vistas de alguns anos para cá, por profissionais da área de saúde e social, de maneira diferente em relação às décadas anteriores. O termo homossexualismo, utilizado até a década de 1980 com a conotação de desvio ou transtorno sexual, vem 
sendo questionado. O sufixo "-ismo", utilizado para identificar doença, passou a ser substituído nas três últimas décadas pelo sufixo "-dade", que transmite a ideia de "um modo de ser" (Sant'Anna \& Daspett, 2007).

Do ponto de vista histórico, "a homossexualidade é tão antiga quanto à própria humanidade" (Frazão \& Rosário, 2008, p. 26). Além disso, o termo homossexual foi criado em 1869 pelo escritor e jornalista austro-húngaro Karl-Maria Kertbeny (Guimarães, 2009). Contudo Sant Anna e Daspett (2007), colocam que a homossexualidade é definida como sendo a atração emocional, física e sexual, por pessoas do mesmo sexo.

Assim sendo, apesar do termo homossexualidade ser menos restritivo e inadequado do que o termo homossexualismo, considera-se que uma pessoa tem muitos modos de ser, e que a sua identidade se compõe de diversos aspectos e não só da orientação sexual, mas do sexo biológico (macho/fêmea), identidade sexual (masculino/ feminino) e aspectos psicológicos (Feijó, 2008; Sant'Anna \& Daspett, 2007).

De acordo com Sant'Anna e Daspett (2007), a homossexualidade, durante muitos anos, foi vista como uma mistura de pecado, doença e crime. Desse modo, rejeições impactantes e variadas foram e ainda são frequentes no contexto social desses indivíduos, o que faz daqueles cujo desejo afetivo-sexual é direcionado para pessoas do mesmo sexo, um dos agrupamentos mais atingidos pelo preconceito, pela intolerância e pela discriminação. Contudo, pessoas com orientação homossexual se desenvolvem e estão presentes em todo tipo de lar e/ou famílias, bem como também estão presentes em vários grupos socioeconômicos, étnicos e religiosos.

Segundo a visão sistêmica e novoparadigmática, as pessoas desejam, amam, se relacionam e se apresentam de forma própria e, ao mesmo tempo, influenciada por contextos e significados que as circundam e dos quais elas fazem parte. Precisam, portanto, ser reconhecidas, aceitas e compreendidas em suas especificidades no âmbito de suas relações familiares e sociais, do seu desenvolvimento e ciclo vital familiar, imersas na cultura (Carter \& McGoldrick, 1995;
Cerveny \& Berthoud, 2009; Horta, 2007; Vasconcelos, 2008).

Para Feijó (2008), considera-se na atualidade uma diversidade dos tipos de família, que podem ser identificadas como famílias monoparentais, famílias ampliadas, famílias reconstituídas e famílias homossexuais, dentre outras.

A família pode ser compreendida como sendo um grupo de pessoas que se relacionam entre si, que possuem laços de afinidade ou de convivência, sem necessariamente estarem ligadas por consanguinidade ou por grau de parentesco (Cerveny, 2011). Existem pluralidades que compõem este cenário, como é o caso das famílias conjugais e extensas, núcleo doméstico e famílias não legitimadas juridicamente (Cerveny, 2011). Portanto, "a família deve ser estudada a partir de uma perspectiva cultural, histórica e intergeracional" (Böing, Crepaldi, \& Moré, 2008, p. 258).

Segundo Galano (2006), família é a estruturação do parentesco com suas possibilidades e imposições. É na família, em primeiro lugar, que a criança geralmente aprende a estruturar o seu cotidiano, tanto por meio da linguagem como através dos seus usos e costumes.

Para Castilho (2009), a família é vista como um sistema complexo de relações que permite aos seus membros o compartilhamento de um mesmo contexto social de pertencimento; é a família que permite aos seus integrantes o reconhecimento das diferenças, o aprendizado de unir-se e separar-se, a construção da identidade, bem como das primeiras trocas afetivo-emocionais.

Além disso, é na família que se aprende e se transmite padrões e modelos como nos coloca Cerveny (2011, p. 51), "toda família repete" e há repetições que diferenciam uma família das demais compondo a identidade desta.

O pensamento sistêmico, aplicado ao campo da terapia familiar, parte do pressuposto de que a família pode ser compreendida como um sistema humano, aberto, com interdependência entre seus membros e o meio, no que diz respeito às trocas de informação. Do ponto de vista sistêmico e novoparadigmático, a família é uma construção, portanto, envolta em significados social- 
mente construídos que a definem e por meio dos quais as pessoas compartilham tais conceitos e a partir deles balizam seus comportamentos, sentimentos e ideias (Grandesso, 2000).

A teoria sistêmica enfatiza as relações entre as partes de um todo em constante interação e interdependências. Os sistemas são totalidades integradas, cujas propriedades não podem ser reduzidas às de unidades menores. Em vez de se concentrar nos elementos ou substâncias básicas, a abordagem sistêmica enfatiza princípios básicos de organização. Todo e qualquer organismo é uma totalidade integrada (Capra, 2006; Vasconcelos, 2008).

Dessa forma, a família, vista como um sistema aberto, resulta da interação e interdependência de suas partes, ou seja, de seus componentes. O ser humano como sistema vivo é um sistema auto-organizador, também pode ser visto como um sistema, mas quando se trata de família, é uma parte, que a influencia e por ela é influenciada. Essa concepção se aplica à terapia familiar sistêmica, que parte do pressuposto de que há interação simultânea e interdependente entre os componentes da família e que esta, vista como um todo, é diferente da mera soma de suas partes. As ideias complexas, portanto novoparadigmáticas, que se integram ao foco sistêmico dado às relações enfatizam, além destas, os contextos (culturais, socioeconomicos) e os processos, tais como o desenvolvimento e os ciclos individual e familiar (Carter \& McGoldrick, 1995; Cerveny $\&$ Berthoud, 2009), dentre outros, ligados aos fenômenos humanos a serem compreendidos, neste caso às famílias e à vivência da homossexualidade. Para Jacobson (2007), a sexualidade se constrói de maneira complexa no sistema familiar e na relação deste com seus subsistemas e com os sistemas extrafamiliares. Nessa perspectiva, a sexualidade é também, de certa forma, aprendida e apreendida, é experimentada por meio de legados familiares, diálogos, toques e impressões. Segundo a autora, a família é um dos eixos construtores da sexualidade.

De acordo com tais pressupostos, a dificuldade da família e de alguns homens aceitarem a própria orientação sexual está inserida em um contexto de relações imersas em crenças, tabus e construções sociais que devem ser vistas conjuntamente. Para compreender o homem com orientação homossexual, e resignificar eventuais conflitos familiares e dificuldades com relação à aceitação da homossexualidade, faz-se necessário ampliar o foco de visão.

O presente trabalho é parte de uma pesquisa qualitativa realizada com o objetivo de compreender a vivência de homens com orientação homossexual e a construção dos significados da homossexualidade em suas respectivas famílias de origem, segundo a visão dos participantes.

\section{Método}

\section{Participantes}

Participaram da pesquisa cinco homens com orientação homossexual, do interior do Estado de São Paulo, Brasil, com idades entre 21 e 25 anos.

\section{Instrumentos}

Os instrumentos utilizados para coleta de dados foram: entrevista semiestruturada e genograma. A entrevista semiestruturada, fundamentada nas referências bibliográficas sobre o tema desse trabalho, contou com um roteiro de perguntas que facilitaram a compreensão a respeito das eventuais dificuldades e conflitos familiares em torno da homossexualidade masculina. O genograma, que é um instrumento constituído por representações gráficas multigeracionais, em cuja elaboração são utilizados símbolos que representam as pessoas, seu sexo biológico, suas relações, casamentos e mortes, além da composição familiar em pelo menos três gerações (Cerveny, 2011), contribuiu para ampliar a compreensão da história da família e das relações familiares do entrevistado.

\section{Considerações Éticas e Procedimentos}

Inicialmente o projeto foi aprovado pelo Comitê de Ética em Pesquisa com Seres Humanos da Faculdade de Medicina de São José do Rio Preto (FAMERP).

O primeiro entrevistado foi contatado por telefone após a indicação da rede social das pes- 
quisadoras. Para agendamento das demais entrevistas, foi utilizado o método "Bola de Neve" (Snow Ball), que consiste em um processo de cooptação, permitindo um acesso em "cadeia" aos participantes do estudo, ou seja, a localização de possíveis entrevistados por indicação dos participantes da pesquisa (Patton, 2002, citado por Sant Anna, 2011, pp. 56-57).

Porém, houve dificuldades dos homens indicados pelo primeiro entrevistado para compareceram às entrevistas agendadas, alegando motivos pessoais. Sendo assim, as pesquisadoras recorreram novamente à sua rede social, para outras indicações do público alvo desta pesquisa e concretização das entrevistas.

Após estabelecer os novos contatos, as mesmas dificuldades se repetiram, mostrando-se coerente com as narrativas obtidas por meio das histórias dos participantes, que demonstraram desconforto para expressarem a sua orientação sexual.

No total, foram contatados dez homens, dentre os quais um desistiu e nove se dispuseram a participar. Destes, quatro não compareceram às entrevistas agendadas e cinco participaram e concederam entrevistas, realizadas em clínicas de psicologia particulares vinculadas às pesquisadoras.

Após terem sido realizados os devidos esclarecimentos, os participantes assinaram o Termo de Consentimento Livre e Esclarecido (TCLE). Os mesmos responderam individualmente à entrevista semiestruturada e as perguntas para construção de seus respectivos genogramas. As pesquisadoras, juntamente com o entrevistado, buscaram compreender as dificuldades enfrentadas por eles ao vivenciarem a sua homossexualidade, bem como a construção dos significados da homossexualidade em suas respectivas famílias de origem.

As entrevistas foram gravadas em áudio, transcritas na íntegra e relidas. A compreensão das narrativas se deu de maneira qualitativa e individualizada, seguindo pressupostos sistêmicos e novo paradigmático (Vasconcelos, 2008) e a proposta de análise de conteúdo de Bardin (2009). Os nomes dos participantes foram alterados para preservá-los, garantindo o sigilo.

\section{Resultados e Discussão}

\section{Perfil dos Entrevistados}

No período de fevereiro a junho de 2012, cinco homens com orientação homossexual na faixa dos 21aos 25 anos participaram da pesquisa. Quatro declararam pertencer a uma determinada religião (católica e evangélica) e um disse não ter religião. Prevaleceu entre os participantes o grau de instrução equivalente ao ensino médio. Dos cinco participantes, um era estudante de ensino superior e não estava trabalhando e quatro trabalhavam, sendo que um deles possuía, também, o ensino técnico profissionalizante. Todos eram solteiros e nenhum tinha filhos. Um residia apenas com a mãe e os demais com os pais.

No que diz respeito à orientação homossexual, todos a comunicaram a alguém da família de origem; quatro declararam a homossexualidade para os pais e um a declarou somente para mãe, ainda vivendo na sociedade como heterossexual.

\section{Genogramas}

A construção do genograma de cada participante permitiu às pesquisadoras a compreensão da composição e história familiar, as expectativas, as repetições de padrões relacionais e de comunicação e as idades de apenas alguns membros das famílias dos entrevistados (Cerveny, 2011; Feijó, 2014).

Considerou-se que famílias e jovens devem ser compreendidos em suas singularidades, bem como em sua história e percurso no desenvolvimento da identidade sexual; que apesar das diferenças, há semelhanças entre as famílias.

Durante a construção do genograma, todos os participantes relataram haver outras pessoas com orientação homossexual em suas famílias, tanto nuclear como extensa. Apesar disso, foram mais frequentes os relatos de rejeição e de falta de informação sobre a homossexualidade, do que os relatos de aceitação e de diálogo aberto sobre o tema, nas famílias, segundo os entrevistados.

As famílias são compostas em sua maioria por homens e poucas mulheres, em especial na origem paterna. Em três dessas famílias há mulheres com orientação homossexual, sendo 
que em uma delas há também uma mulher com orientação bissexual na segunda geração. As outras mulheres com orientação homossexual são da segunda e da terceira gerações. E, em duas famílias, observou-se homens com orientação homossexual apenas na terceira geração.
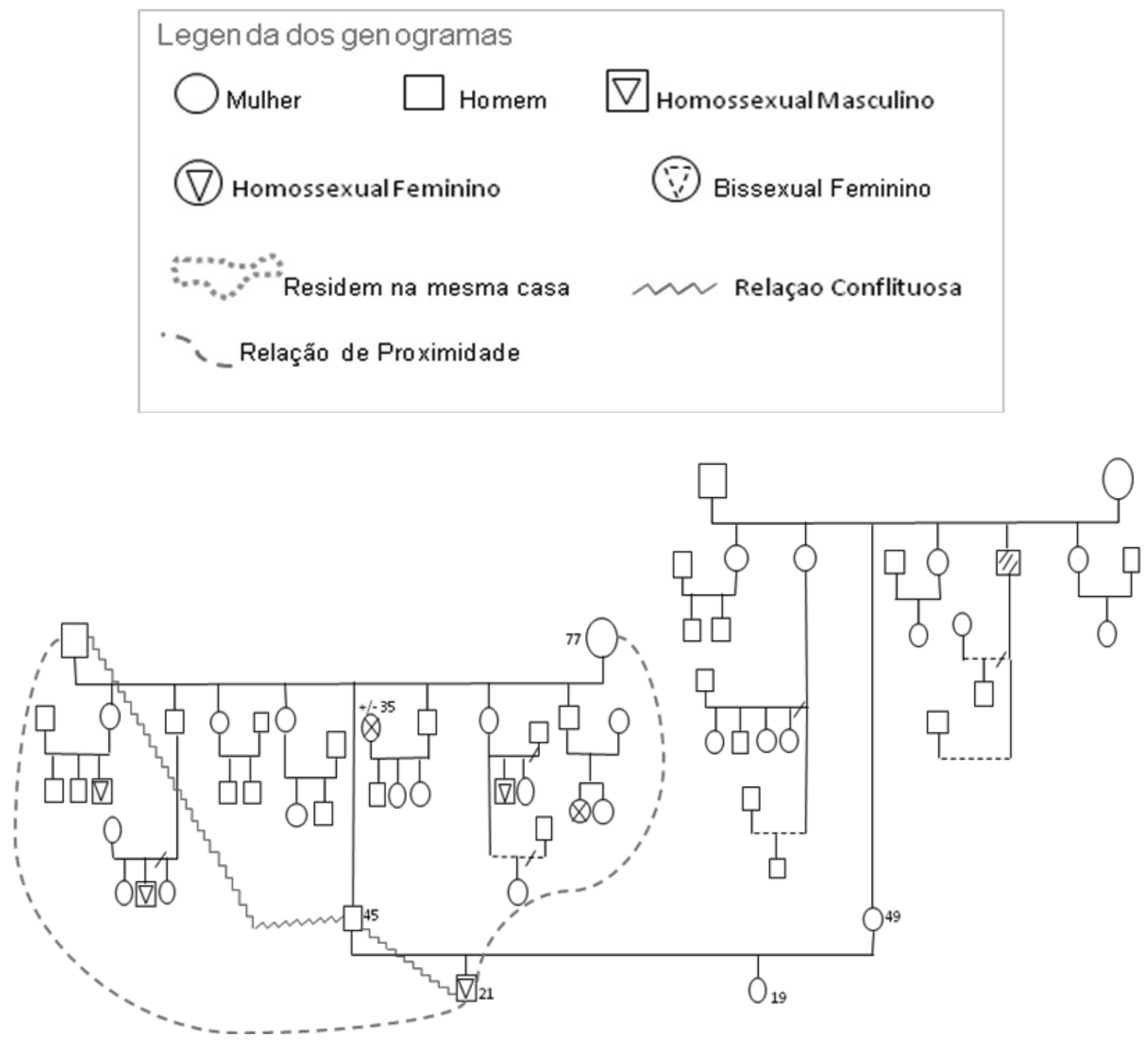

Figura 1. Genograma da família de Roberto.

Roberto reside com os seus pais e sua família é composta por quatro pessoas: ele, a mãe, o pai e uma irmã mais nova. Em sua família de origem paterna, observa-se que duas tias e um tio tiveram filhos homens que apresentam orientação homossexual. O pai de Roberto teve uma relação distante e conflituosa com o seu pai, e este padrão de relacionamento também se repetiu na relação dele com o próprio filho que, apesar de ter um conflito de comunicação e de afetividade com o pai, mantém-se próximo aos avos paternos, numa relação afetiva amorosa.

Com relação a isso Roberto diz:
Vejo muita dificuldade. Principalmente... dentro de casa. É porque com a família quando você tem um relacionamento assim amoroso é difícil vocêficar mentindo com teu pai, com a tua mãe... É ele não entende muito o mundo de hoje; como as coisas funcionam. Eletem a cabeçameiopequena... Eu eтеираi tem um relacionamento bem assim, distante.

Apesar de o entrevistado reconhecer a homossexualidade em outras gerações, ainda há opressão na vivência da sexualidade para Roberto e falta de clareza na comunicação, principalmente com o pai. 


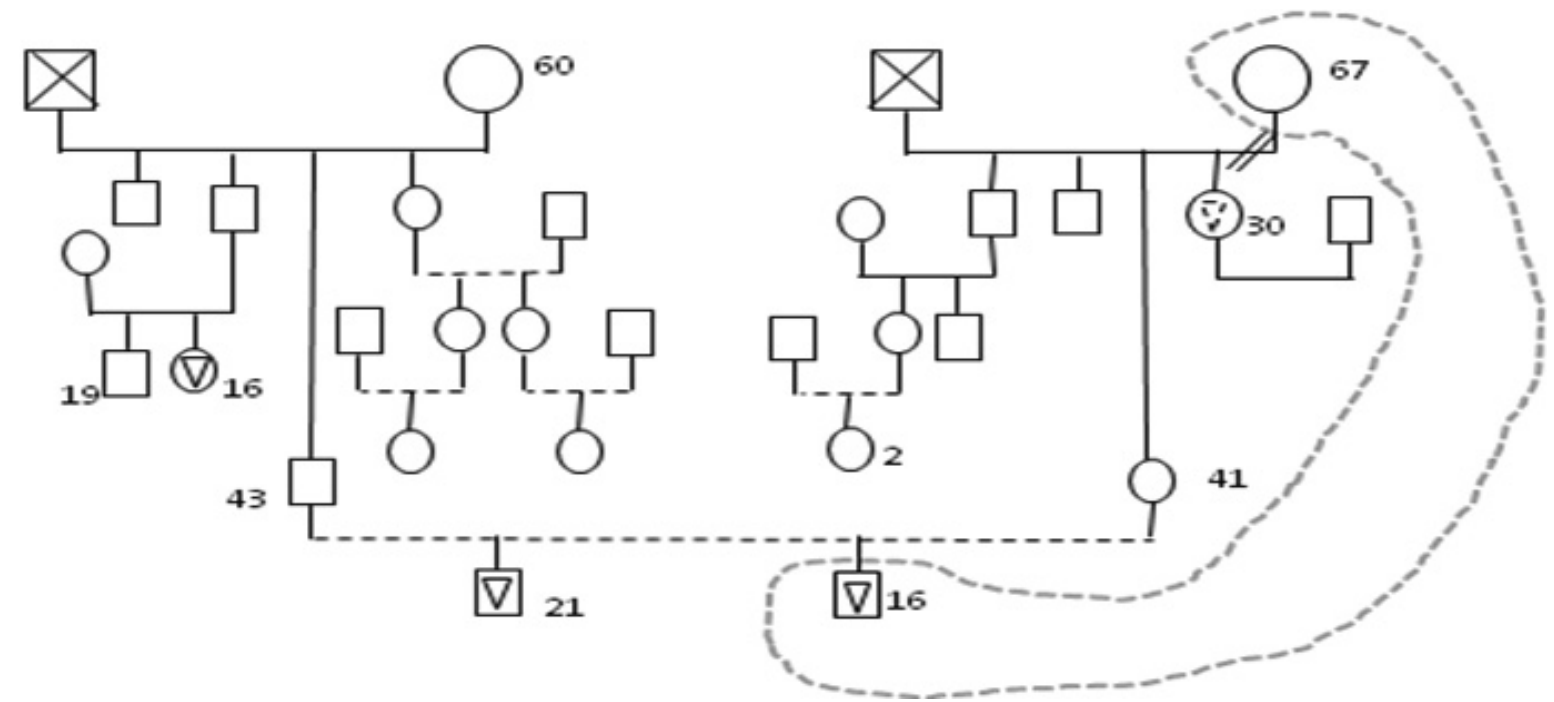

Figura 2. Genograma da família de Murilo.

Murilo reside com os pais e tem um irmão mais novo, que reside com a avó materna e cuja orientação homossexual não foi declarada socialmente. Seus pais têm uma relação estável (não são casados). Na família de origem paterna, um de seus tios tem uma filha mulher com orientação homossexual. E, na família de origem materna, observa-se uma tia com orientação bissexual, casada e sem filhos. Há histórico de uma possível traição conjugal entre os avós maternos que resultou em separação.

Com relação às diferenças individuais entre os irmãos e o segredo em torno da homossexualidade Murilo relata:
Vichi .. . o meu irmão é tudo. Por ele ta muito longe ... eles agrada ... coisas materiais eles sempre deram pra mim, mas de amor e mimo, deu mais pro meu irmão. Aí, eles já imaginam que meu irmão seja, só que também não quer aceitar . . . a hora que ele acha necessário ele fala, porque não me entregou, também não vou entregar ele não ...

A colocação de Murilo, que como as demais foi mantida exatamente conforme falada para aproximar o leitor das formas de expressão dos entrevistados, mostrou-se cheia de conteúdos velados, ressaltando o segredo em torno da homossexualidade que, demonstra ainda não ser fácil a aceitação social da mesma.

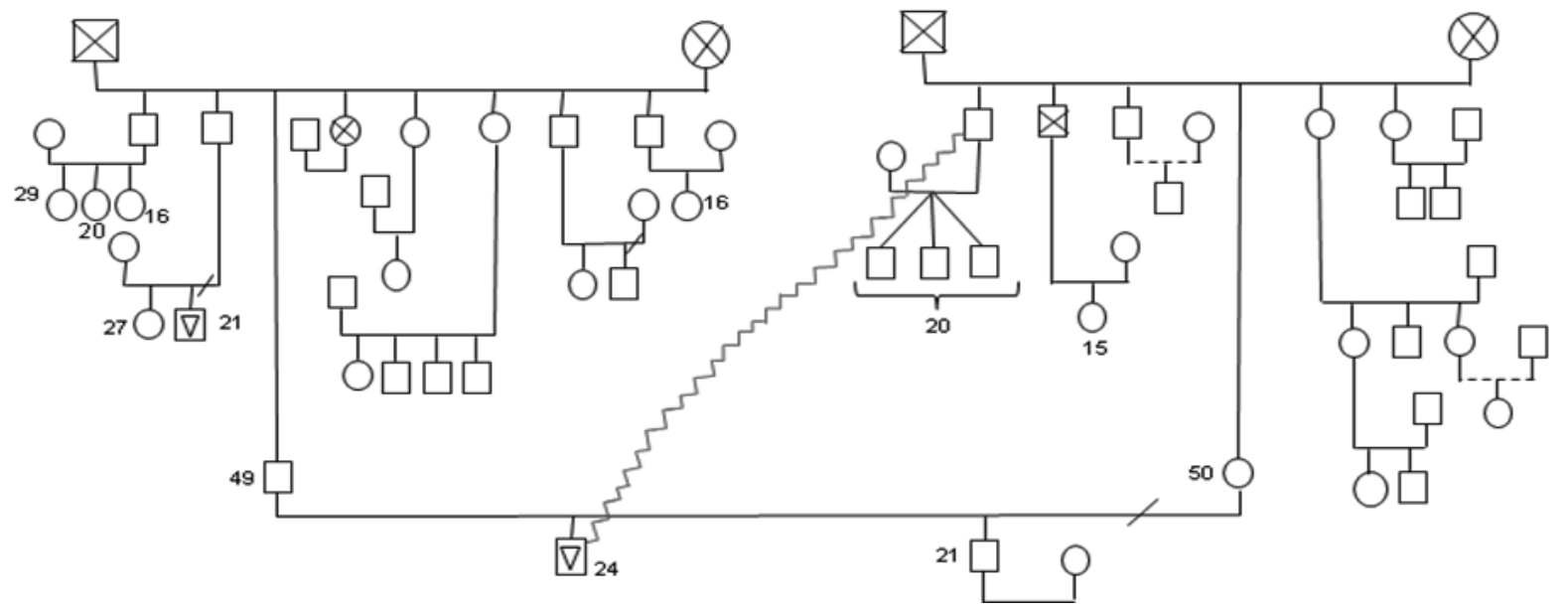

Figura 3. Genograma da família de Danilo. 
Danilo reside apenas com a mãe e sua família é composta por quatro pessoas: seu pai, sua mãe, ele e um irmão mais novo que já é casado, sem filhos. Seus pais estão separados. Em sua família de origem paterna, o filho mais novo de um de seus tios é homem com orientação homossexual. Na família de origem materna, Danilo tem uma relação distante e conflituosa com um dos tios, o primeiro na ordem de nascimento. $\mathrm{O}$ relacionamento de seus pais foi conflituoso até o momento da separação, tornando-se amigável logo após.

A vivência da homossexualidade na família do Danilo é vista por ele sem muitas dificuldades e, a esse respeito relata: "Dentro da minha casa a gente sempre teve orientação da minha mãe, ela sempre conversou muito com a gente. ..." e complementa: "Não me exponho muito... eu procuro... viver dentro dos meus limites...".

Danilo, que mora com a mãe, mas não com o pai, demonstrou estar, possivelmente, em um contexto e provavelmente em um momento da aceitação de sua homossexualidade diferente de outros entrevistados. Vale ressaltar que, as dificuldades relacionadas à expressão e à aceitação da homossexualidade são maiores em relação aos pais do que em relação às mães dos participantes.

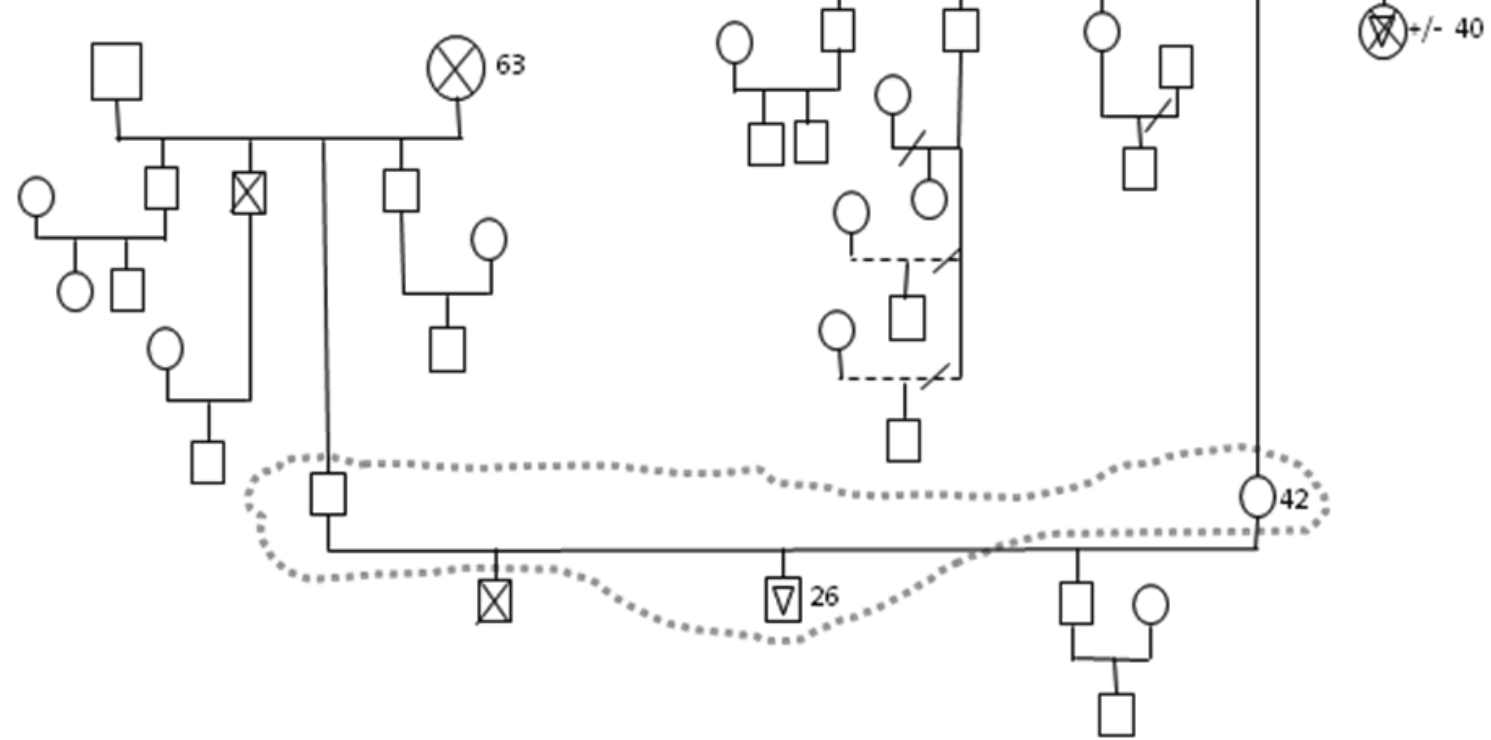

Figura 4. Genograma da família de Bernardo.

Bernardo reside com os pais, sendo ele o segundo filho de uma família de três homens; o primeiro na ordem do nascimento faleceu antes do primeiro ano de vida por complicações de saúde, sobre as quais o participante não quis comentar; o terceiro é casado e tem um filho. Em sua família de origem materna, observa-se uma tia com orientação homossexual, falecida, com quem Bernardo conversava sobre a homossexualidade. Ele não tem conhecimento de conflitos no relacionamento de seus pais com seus avós paternos e maternos; porém, relatou haver certa discriminação dos avós maternos em relação à sua mãe, no período após o seu casamento, por não aceitar o seu cônjuge.

Sobre a vivencia da homossexualidade na sociedade Bernardo coloca:

Por não ter conhecimento, eles acham que a homossexualidade é doença... acha que você vai passar isso para os outros... porque o homossexual não é o que todo mundo pensa ... eu tinha que mostrar pra sociedade, para os meus pais e até mesmo para a minha família, que sempre teve uma opinião formada "contra isso", que não é um "bicho de sete cabeça" que eles pintam. 
Já na sua família ele relata:

... eles me aceitam. Me amam como eu sou

. . . dentro da minha casa, não tem nada que me bloqueia o meu relacionamento com eles ... É tudo bem, é tudo a base de muito dialogo ...
O relato de Bernardo mostra que o diálogo pode trazer, em algumas famílias, melhora na relação e na aceitação da homossexualidade. Ainda assim, Bernardo ressaltou a falta de compreensão, o preconceito e a falta de informações presentes na sociedade.

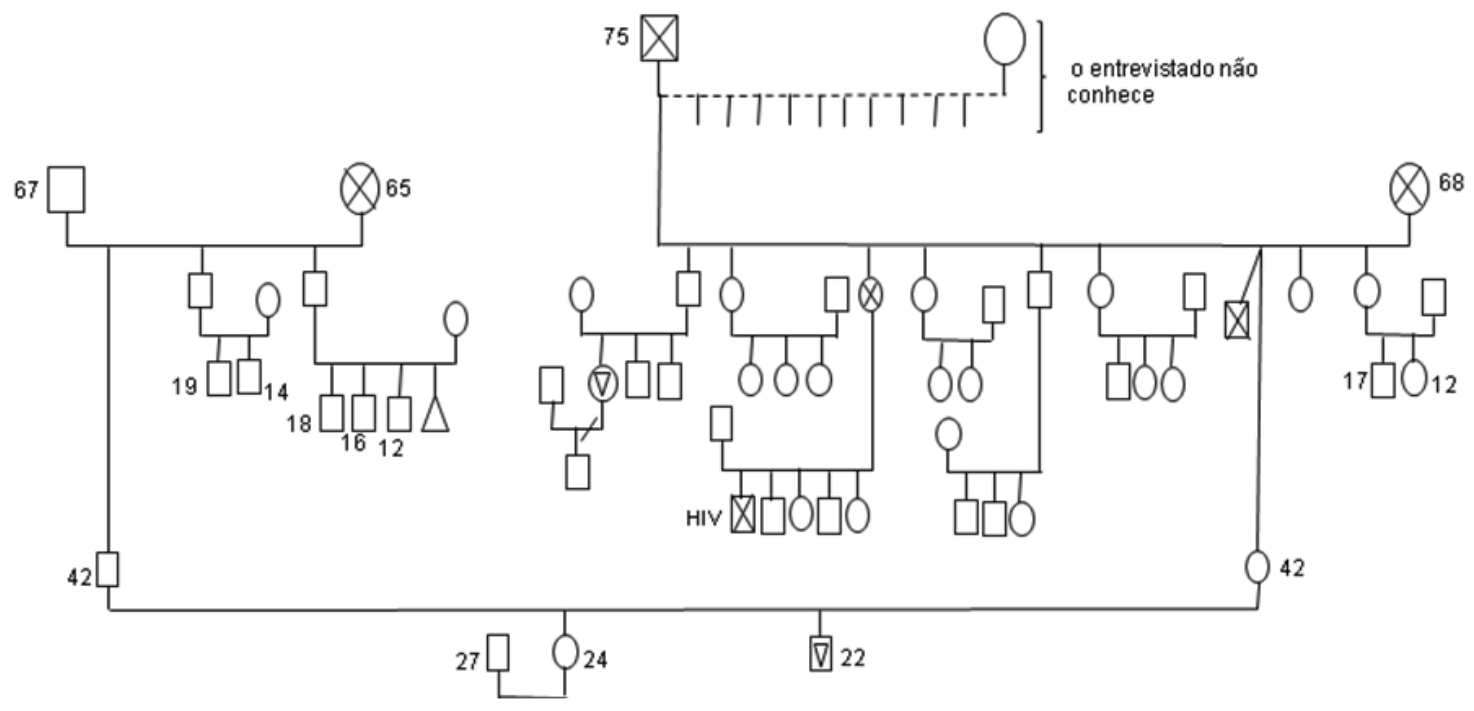

Figura 5. Genograma da família de Caio.

Caio reside com os pais. Ele tem apenas uma irmã mais velha, casada, sem filhos. Observa-se na família de origem materna que um de seus tios tem uma filha com orientação homossexual, a qual é separada de seu marido e tem um filho. Os seus avós maternos já faleceram. A avó paterna faleceu aos 65 anos e o avô está vivo. Seus pais estão com 42 anos e não há relato de conflitos entre os seus pais e seus avós.

Para a família de Caio a homossexualidade é aceita, mas não deve ser comentada como ele mesmo coloca: "minha família, nu começo, não aceitou... mais, com o tempo... só não gosta que eu comento...".

Novamente, os segredos em torno da homossexualidade e as preocupações da família relacionadas à aceitação social da homossexualidade ficaram evidentes, mesmo quando o entrevistado sente-se aceito pelos familiares mais próximos.

\section{Orientação Homossexual: Percepção, Dificuldades e Aceitação}

Com relação à orientação homossexual, no geral, os entrevistados disseram terem tido a percepção de seus desejos homossexuais entre os sete e catorze anos de idade, mas somente na adolescência vieram a expressá-los. A esse respeito Roberto disse:

eu já percebi que gostava do mesmo sexo que eu quando eu tinha sete anos . . . já sabia que eu gostava só que eu nunca me voltei pra esse lado; desde pequeno eu fui me guardando, guardando, guardando até que chegou aonde tá hoje.

Já Murilo se descreve como "um menino sensivel desde criança", contudo foi na sua adolescência que percebeu seus desejos homossexuais: “. . . nos meus 14 anos. É ai que eu fui perceber, eu acho que eu ainda não tinha percebido até eu beijar o primeiro garoto". Segundo Danilo, sua percepção ocorreu quando ainda criança, com a ajuda da mãe, mas no início da adolescência é que teve essa consciência conforme relata: "Desde quando eu era criança, minha mãe falava assim, que eu era fresquinho... Ai, depois disso assim, foi vindo as coisas, a escola. Ai, quando eu tinha 12 anos, não tinha mais jeito...". Cabe observar a forma estereotipada da mãe se referir ao seu comportamento, aparente- 
mente internalizada por ele. Bernardo já se percebia homossexual aos sete, oito anos de idade: "Desde quando eu me entendo como gente. . . uns sete, oito anos eu já me sentia diferente". Caio se percebeu na adolescência: “. . . foi aos 14 anos quando eu tive o interesse de conhecer uma pessoa do mesmo sexo ... e ai eu me relacionei, ai vi que era realmente o que eu queria pra mim".

Há semelhança dos dados da literatura para a maioria dos entrevistados. Na presente pesquisa, a aceitação da orientação homossexual foi permeada por dificuldades, principalmente no sentido de definir e declarar sua identidade sexual frente à família de origem, que em geral espera algo diferente (Horta, 2007). De um modo geral, esta dificuldade aparece no relacionamento entre os participantes e a pessoa do pai. Quando Roberto se refere ao pai, ele diz:

... ele deve desconfiar . . as vezes ele fala assim pra mim: "você já tem 21 anos, nunca trouxe uma namorada dentro de casa . . . você é gay? . . . você gosta de home? Eu não vou te batê; não vou te fazer nada, só quero saber". ... Eu nego ... minto o tempo inteiro para ele .. . Eu e meu pai tem um relacionamento bem assim, distante.

Em relação ao pai, Murilo diz o seguinte: “Meu pai já é uma pessoa que era muito nervosa, só que, depois que descobriu, não falou nada. Me trata normal, não comenta também... meu pai era muito machista". O Danilo também relata:

.. . meu pai é chato até demais e muito rígido... minha mãe conversou com a gente, todo mundo junto aos 12 anos, a gente conversou e foi aí que o meu pai, assim não tem como ele não "sabê", ele já sabia, mas tipo assim, ele procurava; não aceitava, mas a minha mãe conversou... no começo ele ... não aceitou muito, mas depois acabou aceitando. Ao referir-se a pessoa do pai, neste mesmo sentido, Bernardo diz:

pai é sempre mais rígido com relação a essas coisas . . . Apesar que, além disso, teve uma educação bem diferente da minha. Então, eu às vezes posso . . . e devo poupar ele de muita coisa que eu faço ou posso falar...
Caio também relatou:

Ele ficou meio chateado, porque tipo assim, criou um filho pá sê homem, né, aí depois ele vai e gosta da mesma opção sexual dele. Foi dificil no começo... depois, ele aceitô. . . eu cheguei e conversei com ele .. ."Independente da minha orientação sexual, não vou deixá de ser filho do senhor, não vou deixá de gostar do senhor, o senhor não vai deixá de me amar do mesmo jeito, né?". . . Ele ficou um tempo sem conversar comigo... fechou a cara, num cunversava comigo . . . As vezes chorava, mais hoje, é aceito numa boa. Depois da conversa que eu cheguei nele e conversei...

Quando a família de origem não tinha o conhecimento da orientação homossexual, a dificuldade ficava em torno de disfarçar seus comportamentos e sentimentos. Roberto disse o seguinte: “. . . às vezes eu tenho que fazer umas coisas que eu não faço por causa da família, entendeu? Tem que ficar fazendo escondido; tem que tomar cuidado com quem tá olhando". Quanto a isto Murilo relatou:

... foi muito dificil de eu contar... a primeira que sabe é a família, só que tenta ... passar o pano, esconder de si mesmo... Eu me preservava... evitava alguns assuntos com a minha mãe; só que isso pra mim era muito dificil... é difícil você esconder, viver tanto tempo escondendo uma coisa que você é . . . cê anda na rua com medo de alguém te xingar . . demorei em me assumir...

Em relação a este assunto, Danilo diz o seguinte:

Não me exponho muito, porque assim, acho um pouco chato, não pelo o quê os outros vão pensar... ou vão falar... mais assim, por mim mesmo eu procuro, assim, viver dentro dos meus limites, mas assim sabendo o que é pra mim e o que não é pra mim.

No mesmo sentido, Bernardo relata: . . . era bem mais difícil. Qualqué deslize você não sabe se de repente alguém conta ou se eles percebe... você busca muito mais policiar seus atos, suas palavras pra que não aconteça de não dá muito na cara. . . até porque você não sabe qual vai ser a 
reação deles... eu tive que pensar muito $e$ me preparar bastante pra contar isso ... eu já não aguentava mais; pra mim já era um fardo terrivel; já não tinha mais condições de viver com isso guardado.

Caio também diz: "tinha que escondê. . . chegava algum 'caso' meu em casa, eu tinha que falá que era amigo meu, né? ... e não pudia falá pra outra pessoa pra num chegá ao conhecimento deles".

A partir do momento que se declararam homossexuais perante a família, relataram sentir apoio e aceitação para expressar seus desejos, mesmo diante do fato de que, em sua maioria, as famílias não gostam que haja exposição na sociedade ou temem a incompreensão e rejeição social. Neste sentido, Roberto relatou: “. . . contei pra minha mãe e pá minha irmã; pro meu pai eu não contei até hoje . . elas me ajudaram . .

.. O Murilo também relatou:

... minha mãe é uma pessoa que, que eu jamais achei que ela ia aceitá . . . atualmente ela tem aceito até o meu namorado ... eu me assumi por causa dele, porque eu não queria viver uma coisa escondida... a dificuldade que eu tenho pra viver assim é o medo das pessoas, é me julgar antes de me conhecer. Em relação a este assunto, Danilo disse: “. . . a dificuldade assim, foi mais na escola por causa de gracinha, de piadinha . . . minha mãe conversou muito comigo, ela me orientava... como a minha mãe ensinou a gente... que é normal ser diferente...". Bernardo relatou que após contar para a família: “. . . eles me aceitam super de boa... Me amam como eu sou... dentro da minha casa, não tem nada que me bloqueia o meu relacionamento com eles... É tudo a base de muito diálogo...". Quanto a isto, Caio relata: "minha família, nu começo, não aceitou muito não . . . nu momento, eles num quis aceitá... mais, com o tempo também foi, igual aconteceu comigo, eles aceitaram... só não gosta que eu comento, mais normal, eles num critica".

Como observado, as famílias apresentam diferenças no ritmo e na forma de lidar com a comunicação relacionada à orientação homossexual de um filho, mas há mais relatos de dificuldades com os pais do que com as mães, o que está também relacionado aos papéis de gênero socialmente construídos e preservados, que contribuem para a sustentação de atitudes homofóbicas, principalmente por parte dos homens (Butler, 2003; Macedo, 2007). As mulheres, porém, manifestaram mais crenças religiosas, que dificultaram a aceitação da homossexualidade.

As crenças de cada família em torno dos papéis sexuais e sociais pesaram negativamente na aceitação da homossexualidade. Em suas narrativas, os participantes demonstraram as expectativas familiares quanto a manutenção do que é socialmente esperado dos homens e à mudança para uma orientação heterossexual. Sobre isso Roberto relatou:

. . a minha mãe estudou muito tempo com "os testemunha" de Jeová... ela acredita um pouco no que eles ensinam... ela fica falando que eu não devo fazer; que eu devo me guardar por causa da religião... até hoje às vezes eu paro e penso a respeito de eu ser gay. Se realmente eu não devo "pará" $e$ "segui" alguma religião e "abandoná" essa vida ou, eu seja feliz e esquece o resto. Sabe, é complicado.

Quanto a este assunto, Murilo também relata:

. . minha família . . não era muito de frequentar igreja... o que levava eles a não aceitação era o que os outros vão pensar... acreditava que isso era errado, nasceu homem ou mulher, é pra ser homem ou mulher ...

O Danilo diz o seguinte:

. . minha mãe é católica e na Igreja católica é considerado, nem sei como falar... ela falou assim, você é meu filho, eu nunca vou deixar de te amar... meu tio, que ele é evangélico, então, ele leva um pouco mais a sério... minha familia é meio cowboy, sempre tentaram me levar e eu sempre corria. Em relação a este mesmo tema, Bernardo disse:

Eu tenho irmãos... eles se baseiam que a gente vai ser também como eles... eles começam a perceber a diferença... tentam forçar um pouco a barra pra que você mude... constituísse uma família, que isso prova- 
velmente não vai 'acontecê'... esperam que você seja um hetero, que seja um homem, que tenha uma esposa, que tenha filhos $e$ que seja como eles...

Neste sentido, Caio relata:

... é contra as leis da Bíblia, né; intão no começo minha mãe começou a tentá mi explicar, a tentá tirá isso da minha cabeça... isso dai foi mais ela, mais pru lado da religião, né, até em determinado momento eu saí da igreja por causa disso... eu falei... "mãe, si fô pra mim mudá, vai cê com o tempo, porque agora não pretendo" . . . minha mãe é muito religiosa, esse negócio de salvação... ela tentou entrar nesse tópico comigo porque tem partes da biblia que fala também sobre isso... que fosse, assim, como se fosse uma pessoa normal, com orientação sexual normal; como homem e mulher . . . a vontade dela é que eu arrumo uma mulher e case e construo uma família ... ela não consegue me enxergar como homossexual, eu já deixei bem claro pra ela isso, eu falei pra ela: no momento, eu gosto de homem, se algum dia eu caso, por ventura mudá de orientação sexual, me apaixonar por uma mulher, é lógico que eu vou falar eu gosto... mas no momento eu não pretendo isso.

Poucas comunidades religiosas aceitam a homossexualidade. Estudos realizados com homossexuais masculinos, oriundos de comunidades evangélicas, apontaram, por exemplo, que as relações com mulheres são associadas a uma obrigação social, enquanto as ligações com homens são percebidas como expressão de um "querer mais profundo" (Natividade \& Gomes, 2006).

Natividade e Gomes (2006) defende que, os grupos religiosos são um foco importante de mudanças e fala de uma igreja "reformada e inclusiva" que acolhesse os homossexuais em cultos cristãos, sem exigir deles uma mudança de conduta sexual.

Segundo os participantes, a percepção precoce dos desejos homossexuais levou à insegurança e dificuldades que parecem ter permeado a formação da identidade sexual; também evidenciou o medo da rejeição social, diante da escola e rede familiar, além de terem que conviver com a expectativa da família de que viessem a se casar, a ter filhos e de apresentarem comportamentos esperados para homens, principalmente no exercício do papel profissional. Essas dificuldades apontam para uma aceitação parcial ou oscilante, uma pseudoaceitação do filho, com sua orientação sexual e projetos de vida.

Estudos apontam que, assumir publicamente a orientação e a relação homossexual não é fácil e que expressar-se de forma mais aberta é um ato de conquista e de muita coragem para enfrentar todas as turbulências envolvidas. Por outro lado, o sujeito precisa fazer e dizer, para ser alguma coisa. (Freitas, 2012).

\section{Os Significados da Homossexualidade na Família de Origem}

Estudos realizados anteriormente (Cancissu, 2007) fizeram algumas referências a história da homossexualidade. Dentre estes, alguns autores enfatizam que, na antiguidade, a homossexualidade era vista como doença, causada por distúrbios genéticos ou biológicos e também como pecado, baseado no moralismo judaico cristão e, ainda como crime hediondo e perversão sexual, conforme o Direito Romano (Kern \& Silva, 2009).

Tais concepções apareceram de forma explícita ou velada na visão da maioria dos entrevistados sobre ideias de suas famílias, cujas falas, conforme reproduzidas, pareciam carregar preconceitos e estereótipos. Enfatizamos a fala de Caio que, no sentido de pecado, referiu o seguinte:

... Deus fez Adão e Eva, Deus num fez dois Adão e duas Eva . . . era difícil eu aceitá porque eu fui, eu fui ensinado assim: que o homem deve se casar com uma mulher e ter relação com uma mulher e, não homem com homem, nem mulher com mulher...

A religião e suas interpretações a respeito da homossexualidade são com frequência mantenedores de significados negativos que dificultam mudanças necessárias para a aceitação e legitimação da mesma. Acontece que, nessas denominações as crenças religiosas do que é "puro" ou "impuro" dificultam a aceitação e a mudança 
social mais amplas, isto se torna evidente nas situações em que, homens com orientação homossexual afastaram de suas respectivas igrejas para vivenciarem sua homossexualidade ou ainda, procuraram uma igreja "inclusiva" que aceitasse o homossexual, buscando uma participação em congregações que abordavam uma "homossexualidade santificada", que permitisse a vivência da mesma nos moldes cristãos, ou seja, tirando a conotação de pecado da homossexualidade e atribuindo-o às atitudes de promiscuidade, infidelidade, sexo fora do casamento - gay (Natividade, 2010).

A repetição de padrões relacionais é revelada pelo medo de repetição, ou seja, a transmissão da homossexualidade como doença, conforme mostra o relato de Bernardo:

. . . por não ter conhecimento, eles acham que a homossexualidade é doença... acha que você vai passar isso para os outros... porque o homossexual não é o que todo mundo pensa . . . eu tinha que mostrar pra sociedade, para os meus pais e até mesmo para a minha familia, que sempre teve uma opinião formada "contra isso", que não é um "bicho de sete cabeça" que eles pintam.

$\mathrm{O}$ fato de ter que esconder a expressão da sexualidade, reforça o preconceito arraigado nas concepções de homossexualidade como doença, pecado e crime, o que gera o medo e a dificuldade de comunicação. Neste sentido, Roberto relata:

... ser homossexual nessa familia é vivê escondido... Você não pode fazer as "coisa" com liberdade de falá... eu sempre fui muito de "guardá" isso pra mim. Sempre reprimi tudo pra mim... Então acredito que eu fazia assim, segredos dos meus segredos...

Do mesmo modo, Murilo também relata: “. . . meu Deus, se eles pensa que eu gosto disso, eles vai querer acabá comigo, eles nunca vai aceitá". Quanto a isto, Bernardo diz: “. . . eu me fechava com relação a isso... deixei a minha vida intima de lado... eu deixava meus desejos, minhas vontades de lado, porque eu me preocupava com a opinião deles ou de qualquer outra pessoa...".

A projeção de expectativas e papéis das famílias foi destacada pela importância dada ao sucesso nos estudos e na vida profissional, com ênfase no que provavelmente acreditam ser uma imagem social positiva e o papel do homem. Alguns pais manifestaram, porém, a vontade de que os filhos se comportem discretamente, que não exponham sua homossexualidade e que alcancem boas posições na carreira. No que diz respeito a este tema, Roberto relata:

. . minha mãe, ela espera muito de mim, assim: "trabalhá e estudá"... minha irmã... quer que eu me comporte mais... O meu pai, eu não converso muito com ele. Ele só fala comigo de trabalho e só. Acho que ele espera de mim que eu sente com ele e fale de mulher... e "tomá" cerveja e gandaia.

O Murilo diz o seguinte:

... eles querem que eu compre uma casa... dê um jeito na minha vida... que eu tenha as coisas... não gaste dinheiro a toa... mais pro lado da homossexualidade, de hetero, alguma coisa eles num interfere mais, eles quer pra minha vida profissional, que eu estude... me forme num curso superior... ganhe bastante dinheiro... guarde dinheiro... que eu nunca mexa com droga... mas que não inclui a homossexualidade.

Em relação a este mesmo assunto, Danilo disse: “. . . minha mãe procura sempre o melhor pra mim em termos de conhecimento profissional... quer que eu estude muito, mas eu... não quero agora. Eu quero começar a trabalhar e firmar pra eu ver o que eu faço". Quanto a isto, Bernardo também relata: “. . . eles acreditam muito no meu potencial... sabem que eu sou um bom profissional...". No mesmo sentido, Caio relata: ". . . minha mãe sempre comenta comigo de estudo, de formação... que eu seja um profissional... pra mim não pará de estudá...".

Desse modo, as narrativas dos participantes retrataram que a construção do significado da homossexualidade na família de origem se deu por meio de uma concepção preconceituosa e estereotipada, sempre reforçada, em sua maioria pelas crenças religiosas, papéis de gênero, e conceitos de saúde e doença, gerando nos entrevistados um sentimento de medo, ao expressarem sua orientação sexual diante da própria família e sociedade, caracterizando assim, um relacionamento familiar e social discriminatórios. 
Em seus relatos, os entrevistados apontam a necessidade de um trabalho de orientação sexual voltado para as famílias de origem, objetivando facilitar sua convivência na rede social familiar, bem como sua aceitação e autoaceitação com relação à homossexualidade, reconstruindo o seu significado. Vejamos o que o Roberto diz:

... são as que mais precisam de orientação, na verdade. Porque um gay ou um homossexual, ele precisa muito da familia pra "podê encará" isso... E falta muito uma base familiar pro gay "tentá sê" uma pessoa diferente... Acho que "por isso" a maioria dos homossexuais se revoltam, porque parte mais da família, esse preconceito. A família, acho que deveria ser mais orientada do que o homossexual.

A esse respeito, Murilo também diz: “. . . mostrar o que realmente é o gay. Não tentar reverter, porque não tem jeito". Sobre esta proposta, Danilo relata:

... mostrar o que é de verdade [a homossexualidade]; as pessoas pintam muito, fantasiam muito as coisas. Acho que vai ajudar nessa parte da orientação... porque é um pouco complicado até de conversar, porque cada um pensa de um jeito.

Bernardo reforça esta ideia dizendo ". . . acho que pode fazer com que elas [as famílias] entendam ou passem a entender ou "veja" de outra forma [a homossexualidade] . ..". Em relação a este assunto, Caio disse: “. . . tentá ajudá a tê uma aceitação maior pela família... muitas famílias que recriminam... os profissionais pode ajudá a familia a ter uma aceitação maior ou aceitá a opção sexual do filho ou da filha".

Na proposta de reconstrução do significado da homossexualidade, a ressignificação poderá ocorrer por meio das próprias narrativas dos participantes e de suas famílias de origem, tendo o diálogo como recurso para mudança no contexto da terapia familiar sistêmica novoparadigmática, que preconiza a reconstrução de significados de forma que seja ampliada a existência e reduzida a desigualdade social. Significados positivos podem ser atribuídos à homossexualidade e às relações homoafetivas, bem como sobre a história de vida de alguém que sofre com o precon- ceito. Relações familiares podem ser repensadas, fortalecendo laços e abrindo espaços para conversas mais abertas, que por sua vez ampliem a compreensão e a legitimação do familiar com orientação homossexual (Macedo, Bruscagin, \& Feijó, 2014).

De acordo com a compreensão de Grandesso $(2000$, p. 201), "para que haja uma reconstrução de significados, algo deve abalar os significados já instituídos pelos quais organizamos o nosso mundo". Para esta autora, no processo de construção e reconstrução do significado, encontra-se o processo dialógico no qual coevolucionam a singularidade de uma produção individual e uma dimensão social dos atos da fala. Sendo assim, "a conversação dialógica define-se como o contexto no qual e do qual a mudança decorre, tendo terapeuta e clientes como parceiros conversacionais da exploração das narrativas familiares e desenvolvimento de novas e qualitativamente mais ricas possibilidades" (Anderson, 1997; Anderson \& Goolishian, 1988a; Anderson \& Levin, 1998; Sluzki, 1992, 1998, citados por Grandesso, 2000, p. 263).

\section{Considerações Finais}

Cada família é uma família, assim como cada jovem tem sua história e percurso no desenvolvimento da orientação e da identidade sexuais. Contudo, esse estudo demonstrou que os preconceitos socialmente mantidos em relação às diversas formas dos indivíduos vivenciarem sua sexualidade remetem às dificuldades na aceitação da homossexualidade masculina.

A comunicação truncada permeou as relações dos entrevistados, o que pode ser observado pela falta de dados durante as entrevistas, os segredos mantidos nessas famílias e as dificuldades de comunicação ainda mais intensas em gerações anteriores. No entanto, segundo os participantes, as famílias atribuem importância à carreira profissional, esperam dos entrevistados comportamentos discretos, que se aproximem do valorizado socialmente, ou seja, que atendam às expectativas de gênero.

Mudanças em construções sociais e construção de serviços e de novas formas de apoio 
devem ocorrer, para legitimação da diversidade sexual e para o digno atendimento e acesso à direitos de todos os cidadãos. Existem atualmente poucos serviços preparados para o atendimento de saúde a pessoas com diferentes formas de expressão da sexualidade. No Estado de São Paulo, foram criados em 2008 e 2009, dois ambulatórios especializados em atendimentos a transexuais; o primeiro na cidade de São José do Rio Preto, interior, e o segundo na capital (Soares, Feijó, Valério, Siquieri, \& Pinto, 2011). São feitos também alguns atendimentos a homossexuais em grupos de prevenção às doenças sexualmente transmissíveis (DSTs)/AIDS. Assuntos relacionados à homossexualidade são referenciados pela rede digital, como os sites de casais gays; sites de denúncias, discriminação e crimes contra os homossexuais (Defendi, 2010). No que se refere, porém, à legitimação de famílias homoafetivas, casais gays, e pessoas com orientação homossexual em suas famílias de origem, ainda há muito o que fazer para reduzir preconceitos e atos de discriminação, de forma que em casa e na sociedade todas as pessoas tenham seus direitos preservados, inclusive nos serviços sociais e de saúde, independentemente de como vivem a sexualidade e o "jeito próprio de amar".

Grupos religiosos que preconizam a necessidade de mudança de conduta sexual e a cura da pessoa com orientação homossexual são um foco importante de mudanças; pois, na medida em que difundem idéias equivocadas sobre o assunto, mantém preconceitos e atos de discriminação.

Salienta-se que a motivação para este estudo foi o fato de que, em sua prática profissional, os pesquisadores tiveram contatos com jovens e adultos com orientação homossexual, que procuraram atendimento para relatarem suas angústias e medos diante da família e da sociedade, bem como para integrarem seus desejos e fortalecerem a identidade sexual. Entretanto, a maior dificuldade apresentada esteve no fato de levarem tal condição ao conhecimento das famílias. Suas expectativas apontaram para um atendimento familiar mais específico, ou seja, direcionado às famílias de origem dos homens com orientação homossexual, visando facilitar sua vivência sexual na rede social e familiar, que em alguns casos inclui a rede religiosa.

A presente pesquisa não teve como objetivo buscar as causas da homossexualidade, mas sim compreender seu significado no âmbito da família de origem. Sugerimos outras discussões e investigações numa perspectiva intergeracional com o intuito de promover o apoio psicológico a indivíduos, casais e famílias, no contexto da diversidade sexual. Para isto, a visão deverá ser ampliada para a participação da família a fim de resignificar eventuais conflitos relacionados às dificuldades com relação a aceitação da homossexualidade.

\section{Referências}

Bardin, L. (2009). Análise de conteúdo. Lisboa, Portugal: Edições 70.

Böing, E., Crepaldi, M. A., \& Moré, C. L. O. O. (2008). Pesquisa com familias: Aspectos teóricos metodológicos. Paidéia (Ribeirão Preto), 18(40), 251-266. doi:10.1590/S0103$-863 \times 2008000200004$

Butler, J. (2003). Problemas de gênero: Feminismo e subversão da identidade (R. Aguiar, Trad.). Rio de Janeiro, RJ: Civilização Brasileira.

Cancissu, C. R. P. (2007). Lésbicas, família de origem e família escolhida: Um estudo de caso (Dissertação de mestrado, Pontifícia Universidade Católica de São Paulo, SP, Brasil). Recuperado em http:/www.sapientia.pucsp.br/tde_busca/ arquivo.php? codArquivo $=4866$

Capra, F. (2006). O ponto de mutação (A. Cabral, Trad.). São Paulo, SP: Cultrix.

Carter, B., \& McGoldrick, M. (1995). As mudanças no ciclo de vida familiar. Uma estrutura para a terapia familiar (2. ed.). Porto Alegre, RS: Artes Médicas.

Castilho, T. (2009). Família e relacionamentos de gerações. Recuperado em http://www.itfsp.org. br/itfsp/artigos/37-familia-e-relacionamento-de-geracoes

Cerveny, C. M. de O. (2011). A família como modelo: Desconstruindo a patologia (2. ed.). Campinas, SP: Livro Pleno.

Cerveny, C. M. de O., \& Berthoud, C. M. E. (Eds.). (2009). Família e ciclo vital: Nossa realidade em pesquisa (2. ed.). São Paulo, SP: Casa do Psicólogo. 
Defendi, E. L. (2010). Homoconjugalidade masculina, revelação e redes sociais: Um estudo de caso (Dissertação de mestrado em Psicologia Clínica, Pontifícia Universidade Católica de São Paulo, SP, Brasil).

Feijó, M. R. (2008). A família e os projetos sociais voltados para jovens: Impacto e participação (Tese de doutorado em Psicologia Clínica, Pontifícia Universidade Católica de São Paulo, SP, Brasil).

Feijó, M. R. (2014). Genograma no trabalho terapêutico com jovens. In C. M. de O. Cerveny (Ed.), $O$ livro do genograma (pp. 37-44). Rio de Janeiro, RJ: Roca.

Frazão, P., \& Rosário, R. (2008). O coming out de gays e lésbicas e as relações familiares. Revista Análise Psicológica, 26(1) 25-45. doi:10.14417/ ap. 475

Freitas, L. de F. (2012). Sou gay: Uma análise sistêmico-funcional da experiência do "sair do armário". In Anais do XVI Congresso Nacional de Linguística e Filologia - CNLF (pp. 28762891). Rio de Janeiro, RJ: Círculo Fluminense de Estudos Filológicos e Linguísticos. Recuperado em http://www.filologia.org.br/xvi_cnlf/ tomo_3/244_B.pdf

Galano, M. H. (2006). Família e história: A história da família. In C. M. de O. Cerveny (Ed.), Família e... (Cap. 7, pp. 115-147). São Paulo, SP: Casa do Psicólogo.

Grandesso, M. A. (2000). Sobre a reconstrução do significado: Uma análise epistemológica e hermenêutica da prática clínica. São Paulo, SP: Casa do Psicólogo.

Guimarães, A. F. P. (2009). O desafio histórico de "tornar-se um homem homossexual": Um exercício de construção de identidades. Temas em Psicologia, 17(2), 553-567. Recuperado em http:// pepsic.bvsalud.org/scielo.php?pid=S1413$-389 X 2009000200023 \&$ script=sci_arttext

Horta, A. L. de M. (2007). Sexualidade na família: Avanços e desafios da contemporaneidade. In A. L. de M. Horta \& M. Feijó (Eds.), Sexualidade na família (pp. 11-19). São Paulo, SP: Expressão e Arte.

Jacobson, C. M. (2007). A construção da sexualidade na família e seus contextos. In A. L. de M. Horta \& M. Feijó (Eds.), Sexualidade na família (pp. 31-40). São Paulo, SP: Expressão e Arte.
Kern, F. A., \& Silva, L. A. da. (2009, out./dez.). A homossexualidade de frente para o espelho. Psico (Porto Alegre), 40(4), 508-515. Recuperado em http://revistaseletronicas.pucrs.br/ojs/index.php/ revistapsico/article/viewFile/4939/4938

Macedo. R. M. (2007). Sexualidade e gênero. In A. L. de M. Horta \& M. Feijó (Eds.), Sexualidade na família (pp. 20-30). São Paulo, SP: Expressão e Arte.

Macedo, R. M., Bruscagin, C., \& Feijó, M. (2014). Terapia de famílias com filhos adolescentes: Abordagem sistêmica. In G. M. P. Castanho \& M. L. Dias, Terapia de família com adolescentes (pp. 64-78). Rio de Janeiro, RJ: Roca.

Natividade, M. (2010). Uma homossexualidade santificada?: Etnografia de uma comunidade inclusiva pentecostal. Religião e Sociedade, 30(2). doi:10.1590/S0100-85872010000200006

Natividade, M., \& Gomes, E. (2006). Para além da família e da religião: Segredo e exercício da sexualidade. Religião e Sociedade, 26(2), 41-58.

Romualdo, C. (2007). Reflexões sobre a anátomo-fisiologia sexual masculina. In A. L. de M. Horta \& M. Feijó (Eds.), Sexualidade na família (pp. 77-91). São Paulo, SP: Expressão e Arte.

Sant Anna, M. S. (2011). Nem tudo são flores: Um estudo da dinâmica dos conflitos na homoconjugalidade masculina (Tese de doutorado em Psicologia Clínica, Pontifícia Universidade Católica de São Paulo, SP, Brasil).

Sant Anna, M. S., \& Daspett, C. (2007). "O pote de ouro no final do arco-íris": Casais e famílias homossexuais. In A. L. de M. Horta \& M. Feijó (Eds.), Sexualidade na família (pp. 161-174). São Paulo, SP: Expressão e Arte.

Soares, M., Feijó, M. R., Valério, N. I., Siquieri, C. L. dos S. M., \& Pinto, M. J. C. (2011, jan./ abr.). O apoio da rede social a transexuais femininas. Paidéia (Ribeirão Preto), 21(48), 83-92. doi:10.1590/S0103-863X2011000100010

Vasconcelos, M. J. E. (2008). Pensamento sistêmico: $O$ novo paradigma da ciência (7. ed.). Campinas, SP: Papirus.

Recebido: $23 / 04 / 2013$

$1^{a}$ revisão: 24/06/2014 Aceite final: 08/08/2014 